\title{
Breeding habitats and long-term population numbers of two sympatric raptors-Red Kite Milvus milvus and Black Kite $M$. migrans - in the mosaic-like landscape of western Poland
}

\author{
Grzegorz Maciorowski ${ }^{1} \cdot$ Piotr Zduniak $^{2}$ (D) Marcin Bocheński ${ }^{3}$ - Maria Urbańska ${ }^{4}$ Paulina Król $^{5}$. \\ Michał Polakowski ${ }^{5}$ iD
}

Received: 12 December 2019 / Revised: 16 July 2020 / Accepted: 6 August 2020 / Published online: 14 August 2020

(c) The Author(s) 2020

\begin{abstract}
We studied the long-term changes in numbers and habitat structures of two sympatric species-Red Kite Milvus milvus (RK) and Black Kite Milvus migrans (BK) — in two study plots (a mosaic of various habitats and intensive farmland) in western Poland. This research, carried out in two periods (1996-2001 and 2012-2017), did not reveal any significant changes in numbers, or the parameters of breeding success or habitat structure in the territories of either species. The numbers of RK territories in plot A (mosaic of habitats) in the 2 periods were 35 (density: 3.65 pairs/100 km²) and $38\left(3.97 \mathrm{p} / 100 \mathrm{~km}{ }^{2}\right.$ ), whereas the respective figures for BK were $39\left(4.07 \mathrm{p} / 100 \mathrm{~km}^{2}\right)$ and $41\left(4.28 \mathrm{p} / 100 \mathrm{~km}^{2}\right)$. Breeding success was $77.4 / 67.5 \%$ (RK) and 63.9/74.6\% (BK). On study plot B (intensive farmland), the number of RK territories in both periods were ten $\left(1.35 \mathrm{p} / 100 \mathrm{~km}^{2}\right)$ and eight $\left(1.08 \mathrm{p} / 100 \mathrm{~km}^{2}\right)$, while the figures for BK were three $\left(0.41 \mathrm{p} / 100 \mathrm{~km}^{2}\right)$ and five $(0.68 \mathrm{p} / 100 \mathrm{~km})^{2}$, respectively. The breeding success of RK in the two periods was $87.5 \% / 78.6 \%$, respectively; in the case of BK this Figures $(100 \%)$ is known only for the second period. The absence of any changes in population numbers for both species and the high levels of breeding success were probably due to the nest sites and mature woods being subject to conservation measures implemented by the Polish State Forests Administration, as well as lack of major changes to the habitat structures.
\end{abstract}

Keywords Breeding preferences $\cdot$ Conservation $\cdot$ Habitat changes $\cdot$ Black Kite $\cdot$ Red Kite $\cdot$ Numbers $\cdot$ Raptors

\section{Zusammenfassung}

Bruthabitate und Langzeitentwicklung zweier sympatrischer Greifvogelpopulationen - Rotmilan Milvus milvus und Schwarzmilan $M$. migrans - in der mosaikartigen Landschaft Westpolens

Wir untersuchten Langzeitveränderungen in Anzahl und Habitatstrukturen zweier sympatrischer Arten - Rotmilan Milvus milvus (engl. Red Kite, RK) und Schwarzmilan Milvus migrans (engl. Black Kite, BK) - auf zwei Untersuchungsflächen (ein Mosaik aus verschiedenen Habitaten und intensiv bewirtschaftetes Ackerland) in Westpolen. Diese Untersuchung, die in zwei Zeiträumen (1996-2001 und 2012-2017) durchgeführt wurde, ergab keine signifikanten Veränderungen in der Anzahl, bei den Parametern des Bruterfolges oder in der Habitatstruktur der Territorien beider Arten. Die Anzahl an RK-Territorien in der Untersuchungsfläche A (Habitatmosaik) betrug in den zwei Zeiträumen 35 (Dichte: 3.65 Paare/100 km²) und 38 (3.97

Communicated by O. Krüger.

Piotr Zduniak

kudlaty@amu.edu.pl

1 Department of Game Management and Forest Protection, Poznań University of Life Sciences, Wojska Polskiego 71d, 60-625 Poznań, Poland

2 Department of Avian Biology and Ecology, Faculty of Biology, Adam Mickiewicz University in Poznań, Uniwersytetu Poznańskiego 6, 61-614 Poznań, Poland
3 Department of Nature Conservation, Institute of Biological Sciences, University of Zielona Góra, prof. Z. Szafrana 1, 65-516, Zielona Góra, Poland

4 Institute of Zoology, Poznań University of Life Sciences, Wojska Polskiego 71c, 60-625 Poznań, Poland

5 Institute of Biology, University of Szczecin, Wąska 13, 71-412, Szczecin, Poland 
Paare $\left./ 100 \mathrm{~km}^{2}\right)$, während diese für den BK bei $39\left(4.07\right.$ Paare $\left./ 100 \mathrm{~km}^{2}\right)$ und 41 (4.28 Paare/100 km²) lagen. Der Bruterfolg machte 77.4/67.5\% (RK) und 63,9/74,6\% (BK) aus. Auf der Untersuchungsfläche B (intensiv bewirtschaftetes Ackerland) ergab die Anzahl an RK-Territorien in beiden Zeiträumen $10\left(1.35\right.$ Paare $\left./ 100 \mathrm{~km}^{2}\right)$ und $8\left(1.08\right.$ Paare $\left./ 100 \mathrm{~km}^{2}\right)$, während die Zahlen beim BK bei $3(0.41$ Paare/100 km²) bzw. $5(0.68$ Paare/100 km²) lagen. Der Bruterfolg des RK machte in den beiden Zeiträumen 87.5\% bzw. 78.6\% aus. Im Falle vom BK ist die Prozentzahl nur für den zweiten Zeitraum bekannt (100\%). Das Ausbleiben jeglicher Veränderungen der Populationszahlen beider Arten und der hohe Bruterfolg lagen wahrscheinlich daran, dass die Neststandorte und der ausgewachsene Waldbestand Gegenstand von Naturschutzmaßnahmen sind, die durch die staatliche Forstverwaltung Polens eingeführt wurden, sowie daran, dass größere Veränderungen der Habitatstrukturen fehlen.

\section{Introduction}

Human activities involve exploitation of the natural environment. In consequence, they change habitat structures, mainly by modifying previously natural landscapes (Xu et al. 2018). In recent decades, the expansion of logging in forests and the widespread introduction of intensive farming have brought about major habitat changes in the vicinity of human settlements, where traditional mosaic-like landscapes have been replaced by crop monocultures (Grant 2007). Such habitat transformation results in the loss of biodiversity, including that of breeding bird communities (Devictor et al. 2007; Aronson et al. 2014; Seress and Liker 2015; Morelli et al. 2016). There are numerous examples of declines in bird numbers, some even leading to local extinctions, following dramatic changes to their breeding habitats (Donald et al. 2018; Traba and Morales 2019).

Because of their role as apex predators in food webs, birds of prey are particularly vulnerable to environmental changes. Many raptor populations have experienced steep declines and are now endangered (Newton 2010b; https://www.iucnr edlist.org; 2019). The main causes of raptor mortality are poaching, poisoning, collisions with electric power facilities and wind turbines (Guil et al. 2015; Maciorowski et al. $2019 b$ ), as well as natural factors connected with weather conditions and the hardships of migration (Berthold 2001; Newton 2010a). Population declines are also related to the loss of suitable wintering and breeding grounds (Moreau 2009; Maciorowski et al. 2019a). The latter are heavily influenced by habitat conditions, particularly by the quality of foraging areas and the availability of suitable nesting sites (Maciorowski and Mirski 2014; Maciorowski et al. 2019a). The strong tendency to cultivate tall crops (mainly maize Zea mays and rapeseed Brassica napus) as large-area monocultures, with the concomitant, dramatic shrinkage of meadows, wetlands and various types of ruderal vegetation, has markedly reduced food availability for raptors. This has a direct negative effect on the breeding performance, distribution and density of breeding pairs in the case of birds that hunt for prey in open areas (Mammen et al. 2014; Nicolai et al. 2017). Those species that feed on carrion are strongly affected by modern practices in livestock farming. Keeping livestock indoors, together with strict veterinary sanitary regulations, greatly diminishes the amount of carrion available to scavengers (Camina and Yosef 2012; Blanco 2014). Moreover, intensive forest management, focusing on large-scale timber production and often final cutting before trees reach maturity, leads to the shrinkage, or even the local disappearance, of mature woodlands in the vicinity of feeding areas used by raptors as breeding sites.

Black Kite Milvus migrans (BK) and Red Kite Milvus milvus (RK) are examples of raptors whose numbers are declining in many countries (Newton et al. 1996; BirdLife International 2019a, b; Katzenberger et al. 2019). Both species usually nest on tall trees in various types of forest (Cramp and Simmons 1980). While Black Kite often breeds close to water bodies, Red Kite is not so strongly associated with water (Cramp and Simmons 1980; Sergio et al. 2003a, b). Furthermore, both species forage in open, agricultural areas (Carter 2001; Sergio et al. 2003a, b; Mougeot and Bretagnolle 2006), where they often feed on carrion, although Black Kite prefers to hunt for fish in lakes and rivers (Cramp and Simmons 1980). For Red Kite, the availability of foraging grounds consisting of mosaics of arable fields, meadows and wetlands is crucial for its occurrence (Newton et al. 1996; Seaone et al. 2003). Key dangers for both species in the breeding season are intensive farming, leading to the loss of such mosaic-like habitats and thus reducing the abundance and availability of potential prey, as well as collisions with electric power facilities and wind turbines (Schaub 2012; Tavecchia et al. 2012; Tenan et al. 2012; Mammen et al. 2014). The shrinkage of mature woodlands suitable for nesting are also important in this context (Evans and Pienkowski 1991). As scavengers, kites are also very sensitive to illegal bait poisoning (e.g., Tenan et al. 2012; Meyer et al. 2016; Molenaar et al. 2017). On the other hand, supplementary good quality feeding can increase the numbers of local populations, as in the UK (e.g., Orros and Fellowes 2015).

The aim of this study was to investigate the changes in the nesting habitat structures during the last two decades and to compare the number of territories of these two related raptor species in the agricultural landscape of western Poland. The results are discussed in the context of the general decline in raptor numbers in Europe and the importance of protecting nesting and foraging habitats, which act as refuges for rare bird populations and constitute the basis for their survival and further existence. 


\section{Material and methods}

\section{Study areas}

Population estimates for both species and habitat analyses were conducted in two study plots located in western Wielkopolska (W Poland, Fig. 1): Pojezierze SierakowskoMiędzychodzkie (plot A-957.57 $\mathrm{km}^{2}$, coordinates: $52^{\circ} 28^{\prime} 30^{\prime \prime} \mathrm{N}-52^{\circ} 43^{\prime} 15^{\prime \prime} \mathrm{N}$ and $\left.15^{\circ} 44^{\prime} 00^{\prime \prime} \mathrm{E}-16^{\circ} 31^{\prime} 30^{\prime \prime} \mathrm{E}\right)$ and the Mogilnica valley (plot B-738.82 km², coordinates: $52^{\circ} 06^{\prime} 50^{\prime \prime} \mathrm{N}-52^{\circ} 30^{\prime} 00^{\prime \prime} \mathrm{N}$ and $16^{\circ} 14^{\prime} 40^{\prime \prime} \mathrm{E}-16^{\circ} 36^{\prime} 35^{\prime \prime} \mathrm{E}$ ). Plot $\mathrm{A}$ is a mosaic of glacial landforms with a variety of habitats, such as lakes $(n=155)$, ponds, small streams and mature woodlands which, in the vicinity of open areas, area of great natural value. In the north, the plot adjoins the largest forest in Poland, the Puszcza Nadnotecka, which is dominated by mature pine trees. Most of this study plot is protected as a landscape park. Plot B is a radically modified area of intensive farming, typical of this part of the country, with the dominance of large fields of tall crops (mainly maize and rapeseed) and scattered valuable natural sites serving as ecological islands. The landscape characteristics of plot B include hardly any lakes or large water bodies, but there are many small rivers and canals, as well as a variety of rather small wooded areas-immature pine forests on former farmland, small ( $<100$ ha) clumps of old pine forests among arable fields - and mature deciduous forests in the river valleys. The overall habitat structures of both plots are listed in Table 1.

\section{Fieldwork}

BK and RK populations were counted in two periods-1996-2001 and 2012-2017-in accordance with widely accepted criteria, where the general estimate is the sum of occupied and presumably occupied breeding territories in a given year (Postupalsky 1974; Król 1985). In autumn and winter we searched for nests in optimal habitats. Further observations were conducted from vantage points, and we did extensive field research at the beginning of the breeding season (from March until the beginning of May).

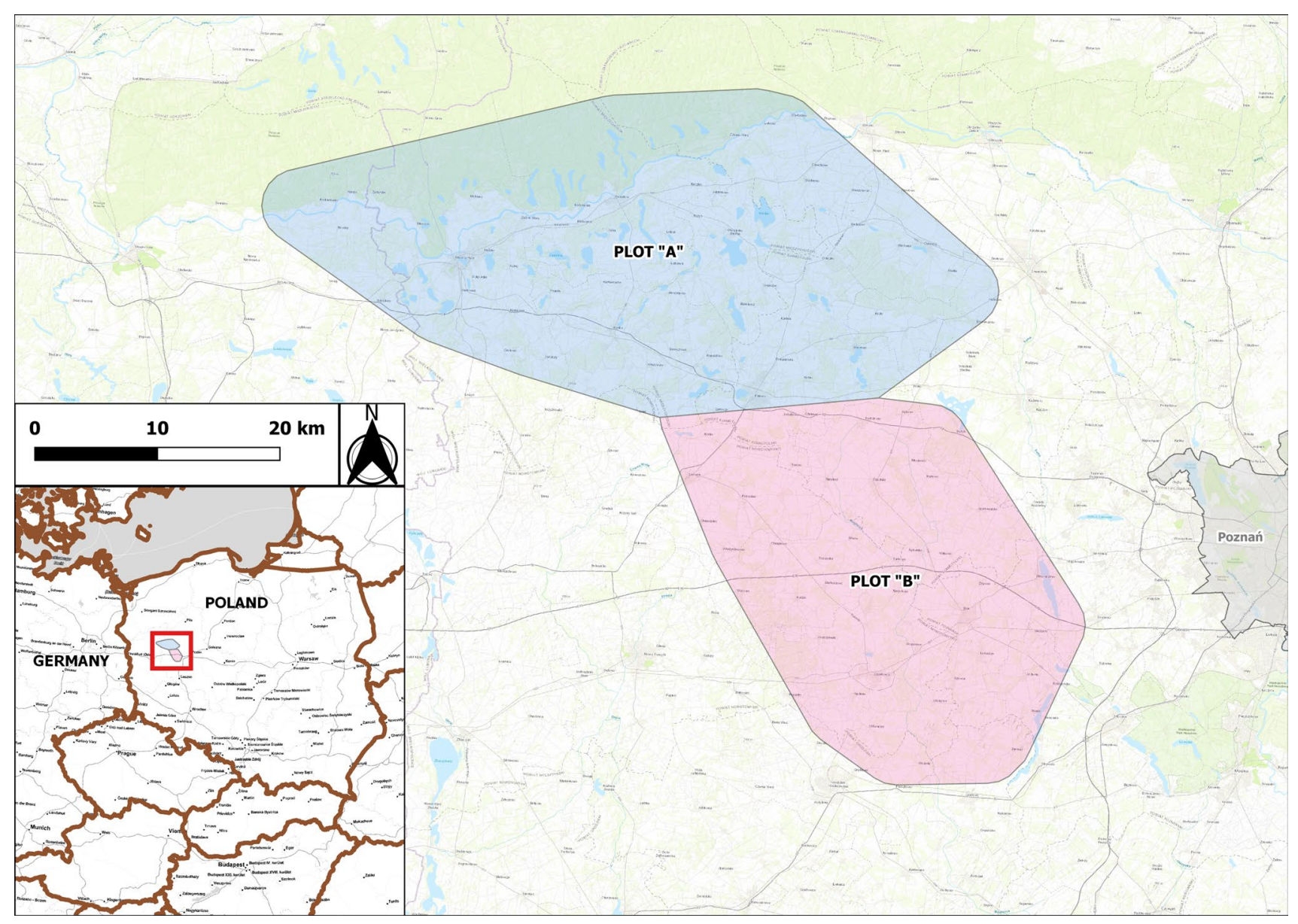

Fig. 1 Location of the study areas: plot A-Pojezierze Sierakowsko-Międzychodzkie and plot B-the Mogilnica valley 
In this paper, we use the total number of breeding territories recorded in the study plots in each period. Breeding success is measured as the number of broods where at least one chick fledged in relation to the total number of occupied nests (stated as a percentage). The number of chicks was recorded during on-site nest inspections just before they left the nests.

\section{Data processing and analysis}

We used Corine Land Cover (CLC) data to describe the overall habitat structure of the two study plots: CLC 2000 for period 1 (1996-2001) and CLC 2012 for period 2 (2012-2017). The data were derived from the Copernicus Land Monitoring Service (C European Union 2017). Using QGIS software (QGIS Development Team 2017), we calculated the area and percentage of the following land cover classes in each study plot: artificial surfaces (CLC class one), arable land and permanent crops (CLC classes 2.1 and 2.2), pastures (CLC class 2.3), heterogeneous agricultural areas (CLC class 2.4), forest and shrub (CLC class three), wetlands (CLC class four) and water bodies (CLC class five).

For each nest we recorded the GPS coordinates and, using the same QGIS software, we set up two buffer areas: (a) within a radius of $100 \mathrm{~m}$ around a nest as the nest site habitat, (b) within a radius of $3000 \mathrm{~m}$ around a nest as the territory habitat. The choice of the $3 \mathrm{~km}$ buffer was based on the characteristics of the areas studied, breeding density and information about the kites' home range size (see Pfeiffer and Meyburg 2015). We calculated the area of each buffer and the percentage of the land cover classes mentioned above. On the basis of these data, we then calculated Shannon's diversity index $\mathrm{H}$ as the habitat diversity index for each study plot, nest site buffer and territory buffer (Magurran 2004).

Canonical Variates Analysis was applied to analyse the effect of time period on changes in habitat structure (Ter Braak and Šmilauer 2002), with the time period as a binary dependent variable and eight environmental factors (the seven habitat components listed above and Shannon's
H) as independent variables. The analyses in study plot A were performed for each kite species separately. In study plot B, however, there were too few territories to perform separate analyses for each species (especially in the case of BK). The two species were therefore analysed together. To control for the species effect, the species (as a binary variable: BK and RK) was included in the models as a covariate. The significance of the models as well as the significance of the tested factors were estimated during forward selection using the Monte Carlo Permutation (MCP) test set for 5000 permutations and CANOCO for Windows 4.5 (Ter Braak and Šmilauer 2002). Throughout the text, mean values are shown with standard deviations ( \pm SD).

\section{Results}

\section{Habitat structure of the study plots}

Overall, study plot A was more diverse than plot B (Shannon's H; Table 1). Taking into account the structure of the main habitat components in both study periods (Table 1), plot A had on average 2.8 times more forest and 1.5 times less arable land than plot B. Moreover, plot A had 45.7 times more aquatic habitats (watercourses, water bodies) and only 1.2 times fewer anthropogenic habitats (built-up areas, roads, etc.; Table 1). The overall habitat structures of the two study plots did not differ significantly between the periods compared. The differences varied from 0.04 to 1.27 percentage points in plot $\mathrm{A}$, and from 0.12 to $1.33 \%$ points in plot B (Table 1).

\section{Number of territories}

The total numbers of territories occupied by both species in both study periods were higher in plot $\mathrm{A}$ than in plot $\mathrm{B}(\mathrm{RK}$ : Chi square test, $\chi^{2}=16.62$, df $=1, p<0.001$; BK: $\chi^{2}=29.45$, $\mathrm{df}=1, p<0.001$, Fig. 1). Furthermore, the numbers of territories occupied by both species on both study plots did not

Table 1 The overall landscape structure of the two study plots (A-Sieraków, B-Mogilnica) in two periods (1-1996-2001, 2-2012-2017)

\begin{tabular}{|c|c|c|c|c|c|c|c|c|c|}
\hline Study plot & Period & $\begin{array}{l}\text { Arable lands } \\
\text { and perma- } \\
\text { nent crops } \\
(\%)\end{array}$ & Pastures (\%) & $\begin{array}{l}\text { Heterogene- } \\
\text { ous agricul- } \\
\text { tural }(\%)\end{array}$ & $\begin{array}{l}\text { Forests and } \\
\text { shrubs }(\%)\end{array}$ & $\begin{array}{l}\text { Wetlands } \\
(\%)\end{array}$ & $\begin{array}{l}\text { Water bodies } \\
(\%)\end{array}$ & $\begin{array}{l}\text { Artificial } \\
\text { surfaces }(\%)\end{array}$ & $\begin{array}{l}\text { Shanon's H } \\
\text { index }\end{array}$ \\
\hline \multirow{3}{*}{$\begin{array}{l}\mathrm{A}- \\
957.6 \mathrm{~km}^{2}\end{array}$} & 1 & 50.46 & 3.22 & 5.84 & 34.42 & 0.13 & 4.43 & 1.50 & 1.51 \\
\hline & 2 & 49.19 & 3.18 & 5.59 & 34.58 & 0.24 & 4.46 & 2.77 & 1.57 \\
\hline & Mean \pm SD & $49.83 \pm 0.90$ & $3.20 \pm 0.03$ & $5.72 \pm 0.18$ & $34.50 \pm 0.11$ & $0.19 \pm 0.08$ & $4.45 \pm 0.02$ & $2.14 \pm 0.90$ & $1.54 \pm 0.04$ \\
\hline \multirow[t]{3}{*}{ B-738.8 km² } & 1 & 76.09 & 6.81 & 2.91 & 12.16 & 0.15 & 0.10 & 1.78 & 1.00 \\
\hline & 2 & 74.76 & 6.33 & 2.38 & 12.69 & 0.27 & 0.10 & 3.48 & 1.09 \\
\hline & Mean \pm SD & $75.43 \pm 0.94$ & $6.57 \pm 0.34$ & $2.65 \pm 0.37$ & $12.43 \pm 0.37$ & $0.21 \pm 0.08$ & $0.10 \pm 0.00$ & $2.63 \pm 1.20$ & $1.05 \pm 0.06$ \\
\hline
\end{tabular}


differ significantly between the two periods (Plot A: RK: $\chi^{2}=0.12, \mathrm{df}=1 p=0.725$; $\mathrm{BK}: \chi^{2}=0.05, \mathrm{df}=1, p=0.823$; Plot B: RK: $\chi^{2}=0.22, \mathrm{df}=1, p=0.637 ; \mathrm{BK}: \chi^{2}=0.50, \mathrm{df}=1$, $p=0.479$; Fig. 2).

\section{Habitat composition in the territories and in the vicinity of nests}

\section{Nest site habitat}

We analysed the main components of the habitat structure in the $100 \mathrm{~m}$ radius buffers around the nests for both species in both study plots and in both periods (Table 2). The Canonical Variates Analysis model performed for Red Kite in plot A with all the explanatory variables did not show up any differences between the periods, as the model was insignificant (MCP test; first canonical axis: $F=2.75, p=0.769$; all canonical axes: $F=0.55, p=0.769$ ). The same CVA model performed for Black Kite in plot A was significant (MCP test; first canonical axis: $F=15.87, p=0.005$; all canonical axes: $F=3.17, p=0.005$ ) but only one factor exhibited a significant discrimination ability between the time periodsthe percentage of arable land and permanent crops (MCP test, $F=13.39, p<0.001$, Table 2 ). The analysis performed for plot B, with species as a co-variate in the model, did not reveal any differences between the periods, as the CVA model was insignificant (MCP test, first canonical axis: $F=3.57, p=0.542$; all canonical axes: $F=0.89, p=0.542$ ).

\section{Territory habitat}

We analysed the main components of the habitat structure in the $3000 \mathrm{~m}$ radius buffers around the nests for both species in both study plots in both periods (Table 3 ). The CVA model performed for Red Kite in plot A with all the explanatory variables was significant (MCP test; first canonical axis: $F=26.20, p<0.001$; all canonical axes: $F=3.74, p<0.001$ ), where three factors showed a significant discrimination ability between the time periods: percentage of anthropogenic habitats (MCP test, $F=8.81, p=0.003$ ), percentage of arable land and permanent crops $(F=6.70, p=0.010)$, and overall landscape diversity as expressed by Shannon's H (MCP test, $F=4.53, p=0.037$; Table 3). The same CVA model performed for Black Kite in plot A was also significant (MCP test; first canonical axis: $F=18,80, p=0.014$; all canonical axes: $F=2.69, p=0.014$ ), where two factors showed a significant discrimination ability between the periods compared: percentage of water bodies (MCP test, $F=5.72$, $p=0.018$ ), and overall landscape diversity as expressed by Shannon's H (MCP test, $F=7.91, p=0.006$; Table 3).

The CVA model performed for plot B with species as a co-variate was also significant (MCP test; first canonical axis: $F=165.42, p<0.001$; all canonical axes: $F=23.64$,

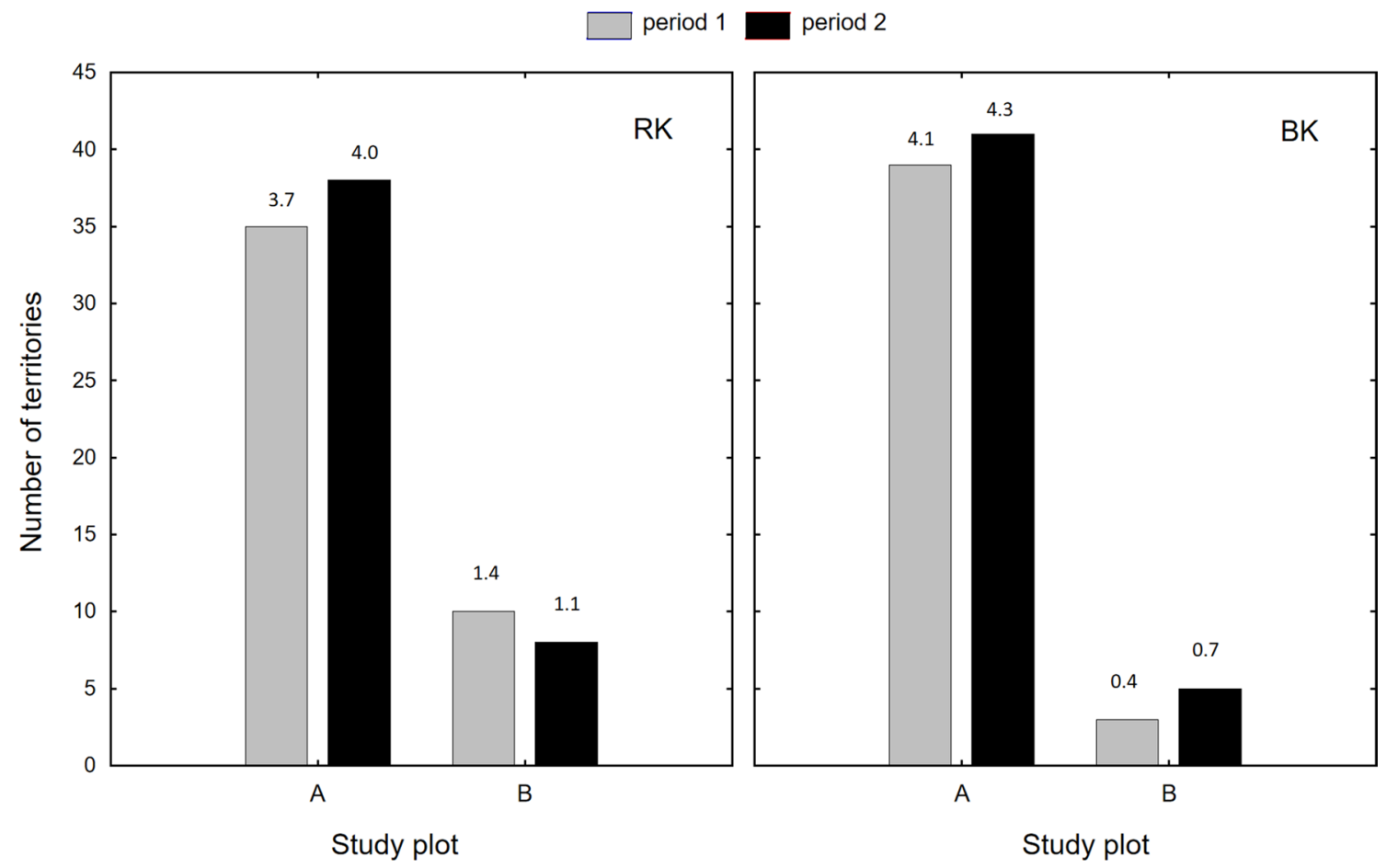

Fig. 2 The number of territories of Red Kite (RK) and Black Kite (BK) in the two study plots (A-Sieraków, B-Mogilnica) in two periods (1-1996-2001, 2-2012-2017); the values above the bars indicate densities of territories per $100 \mathrm{~km}^{2}$ 


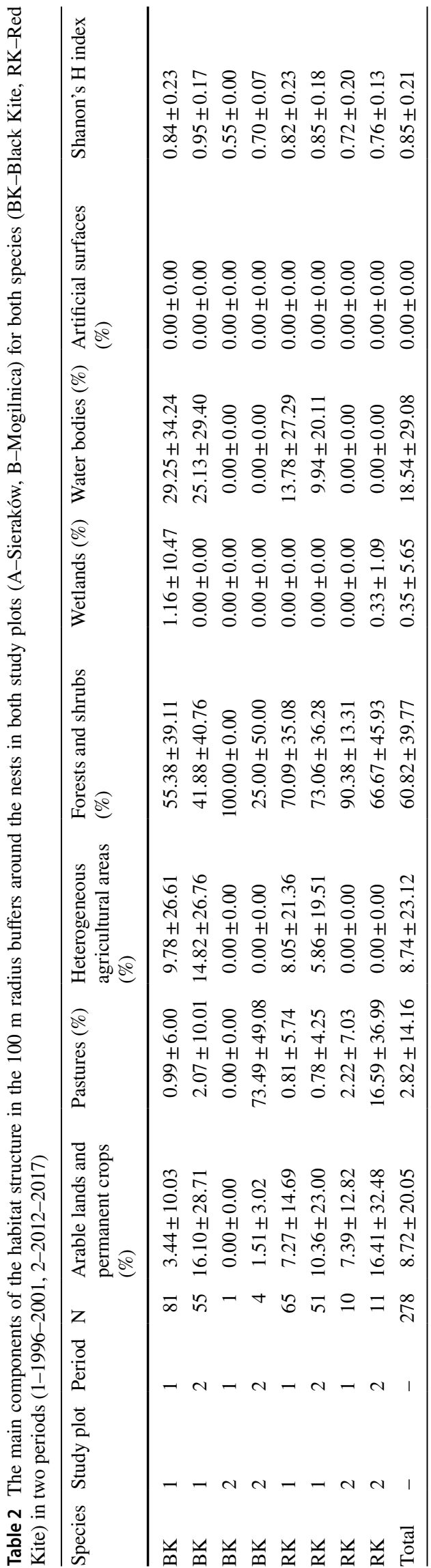

$p<0.001)$ and two factors were significant within the model: percentage of water bodies (MCP test, $F=13.47$, $p<0.001$; period 1 : mean $=1.35 \pm 1.86 \%$, period 2 : mean $=0.60 \pm 1.44 \%)$ and percentage of arable lands and permanent crops $(F=32.69, p<0.001$; period 1 : mean $=71.12 \pm 12.60 \%$, period $2:$ mean $=75.79 \pm 8.10 \%$ ).

\section{Breeding success}

We analysed the parameters describing the breeding success of both species in both study plots and in both periods (Table 4). In plot A, there were no differences in the parameters between the two periods for either species, except for the mean number of fledglings in all active Black Kite nests, which was significantly higher in the second period (Mann-Whitney $U$ test, $Z=-2.45, p=0.014$, Table 4). The same analyses performed for plot $B$ showed no differences between the two periods in any of the Red Kite breeding parameters (in all cases $p<0.05$, Table 4 ). These analyses for Black Kite were not carried out owing to the small sample size.

\section{Discussion}

Both study plots differed in their habitat structure and landscape variety, which in turn gave rise to large differences in the population densities of the two kite species. Plot A, the more diversified one, was a very important breeding area for both species. Densities of breeding pairs of Black Kite (4.07-4.28 pairs $/ 100 \mathrm{~km}^{2}$ in plot $\mathrm{A}$ in the two periods, respectively) were consistent with the average densities in this part of Europe (1-20 pairs/100 km²; Rutschke 1983; Gedeon and Stubbe 1991, 1992). However, this species can occur in much higher densities: e.g., along the River Reuss in Switzerland-48 p/100 km² (Fusch 1980); near Halle (Germany)-80-130 p/100 km² (Gedeon and Stubbe 1991, 1992) or even $151 \mathrm{p} / 100 \mathrm{~km}^{2}$; and as many as $1008 \mathrm{p} / 100 \mathrm{~km}^{2}$ in Spain (see the review in Sergio et al. 2005). The density of breeding pairs of Red Kite ( 3.65 and $3.97 \mathrm{p} / 100 \mathrm{~km}^{2}$ in plot $\mathrm{A}$ in the two periods, respectively) was also consistent with the average densities recorded in Europe $\left(1-15 \mathrm{p} / 100 \mathrm{~km}^{2}\right.$; Gedeon and Stubbe 1992, 1993). On the other hand, it was much lower than the high densities found in southern Spain (32 p/100 km², Sergio et al. 2005) and eastern Germany (37-47 p/100 km² ; Nicolai 1995). In 1979, for instance, $13 \mathrm{~km}^{2}$ of forest around Magdeburg hosted as many as 136 breeding pairs of Red Kite (Mebs 1989). The densities recorded in plot $\mathrm{B}-1.35 / 1.08 \mathrm{p} / 100 \mathrm{~km}^{2}$ for Red Kite and $0.40 / 0.67 \mathrm{p} / 100 \mathrm{~km}^{2}$ for Black Kite-are among the lowest values in Europe (Gedeon and Stubbe 1992, 1993): this is due to the relatively small area of suitable nesting habitats for both species in the plot. 
Our data on the breeding performance of both species were also very close to the parameters recorded in other parts of Europe. We found no major changes in these parameters between the two study periods. The level of breeding success was relatively high, which was at least partly due to the conservation of nest sites and nesting areas by the State Forests Administration. The fact that the study area is one of the key breeding grounds of both species in Poland makes this high breeding success even more significant (Maciorowski 2017; Maciorowski et al. 2019b). The breeding success of Black Kite in plot A was $63.9 \%$ and $74.6 \%$ in the two periods, respectively, whereas that of Red Kite was $77.4 \%$ and $67.5 \%$, respectively. The figures for Black Kite were slightly higher than for the population in Silesia, southern Poland (61.3\% successful broods; Adamski 1992) and around Magdeburg (63.5\%; Gedeon and Stubbe 1992). On the other hand, very similar results were obtained in Switzerland (69.0\%, Glutz et al. 1971) and elsewhere in Germany (69.7-90.3\%; Mammen et al. 2017). The breeding success of the Red Kite population we studied was consistent with the values recorded throughout Europe. It was slightly higher than in Silesia (Adamski 1994) and in Wales (Davies and Davis 1973), where it was $65 \%$ and 50\%, respectively, but lower than the average breeding success for the German population recorded during 25 years $(81.1 \%$; Mammen et al. 2017).

The mean number of Black Kite fledglings per breeding pair in Europe is 1.30 (Mebs 1989). This is very close to the results recorded in plot A $(1.31 / 1.81)$, which were higher than the figures for Silesia (1.2; Adamski 1992) and southern Spain (0.71-1.24; Sergio et al. 2005) but similar to the means for the German and Swiss populations (1.72/1.5; Glutz et al. 1971; Mammen et al. 2017). The mean numbers of Black Kite fledglings per pair with breeding success in plot A were 2.05 and 2.33 in the two periods, respectively; these values are similar to those recorded at the majority of European sites, including Silesia, Germany and Switzerland (Glutz et al. 1971; Adamski 1992; Gedeon and Stubbe 1992; Mammen et al. 2017) and within the wide range of this parameter (1.10-2.14) recorded in Spain (Sergio et al. 2005). The mean brood productivity of Red Kite in plot A was 1.55 and 1.43 fledglings per pair as well as 1.98 and 2.11 fledglings per pair with breeding success (in both periods respectively). These values are similar to those for the German (1.72/2.12; Mammen et al. 2017) and Silesian (1.4/2.3; Adamski 1994) populations, but higher than for the Welsh (0.7/1.3; Davies and Davis 1973) and Spanish (0.76/1.55; Sergio et al. 2005) populations.

As in plot A, the breeding success of both species in plot B was relatively high. This suggests that the birds can effectively utilize appropriate breeding sites in spite of their scarcity and that these sites are properly protected by the State Forests Administration. Breeding success in plot B in 
Table 4 Breeding performance of Black Kite (BK) and Red Kite (RK) in the two study plots (A-Sieraków, B-Mogilnica) in two periods (1-1996-2001, 2-2012-2017)

\begin{tabular}{llllll}
\hline Species & Study plot & Period & Breeding success (\%) & $\begin{array}{l}\text { No. fledglings-all } \\
\text { active nests }\end{array}$ & $\begin{array}{l}\text { No. fledglings- } \\
\text { nests with success }\end{array}$ \\
\hline BK & 1 & 1 & $63.9 ; 54.5-72.4(119)$ & $1.31 \pm 1.16(119)$ & $2.05 \pm 0.76(76)$ \\
BK & 1 & 2 & $74.6 ; 62.9-84.2(71)$ & $1.81 \pm 1.22(55)$ & $2.33 \pm 0.84(43)$ \\
BK & 2 & 1 & Nd & Nd & Nd \\
BK & 2 & 2 & $100.0 ; 29.2-100.0(3)$ & $3.00 \pm 0.00(3)$ & $3.00 \pm 0.00(3)$ \\
RK & 1 & 1 & $77.4 ; 66.7-85.8(84)$ & $1.55 \pm 1.12(84)$ & $1.98 \pm 0.85(64)$ \\
RK & 1 & 2 & $67.5 ; 56.1-77.5(80)$ & $1.43 \pm 1.20(68)$ & $2.11 \pm 0.82(46)$ \\
RK & 2 & 1 & $87.5 ; 47.4-99.7(8)$ & $1.37 \pm 0.92(8)$ & $1.57 \pm 0.79(7)$ \\
RK & 2 & 2 & $78.6 ; 49.2-95.3(14)$ & $2.08 \pm 1.62(12)$ & $2.78 \pm 1.20(9)$ \\
\hline
\end{tabular}

Breeding success is shown with binominal confidence intervals and mean values are given with $\pm \mathrm{SD}$; the numbers in parentheses represent the number of inspected occupied nests; note the small sample size for the second study area. $N d$ no data available

$N d$ no data available the second period was $100.0 \%$ for Black Kite and $78.6 \%$ for Red Kite, with 3.0 and 2.1 fledglings per pair, respectively. These values are extremely high, comparable with the highest figures recorded in Europe. They confirm that the birds occupy the most optimal habitats, which serve as ecological islands in a region substantially modified by intensive farming (Mammen et al. 2017). However, one should bear in mind that the sample size was very low owing to the specific habitat structure of the study plot.

We did not find any major long-term changes in the structures of the breeding and foraging habitats of either species in the two study periods. Statistically significant changes in nest site habitat structure between these periods related only to Black Kite in plot A and the percentage of arable land and permanent crops (3.44\% vs. $16.10 \%)$. The maximum significant changes in the territory habitat structures studied in plot A affected the percentage of anthropogenic habitats in Red Kite territories (1.4\% vs. $2.9 \%$ ) and the percentage of water bodies (7.2\% vs. $5.9 \%)$ in Black Kite territories. The statistically significant changes in the territory habitats between the two periods in plot B pertained only to the percentage of water bodies $(1.3 \%$ vs. $0.6 \%)$ and the percentage of arable land and permanent crops ( $71.1 \%$ vs. $75.8 \%)$. In all these cases, the degree of changes in the environment, even if they were statistically significant, did not seem to be of any biological relevance. This is probably why the population numbers did not change, as the birds were still able to find optimal living conditions in the study area. The mosaic of agricultural, forest and (to a smaller extent) aquatic habitats, described in this paper, corresponds to the habitat preferences of both species in this part of Europe (Nicolai et al. 2017). Similarly, records of Black Kite breeding in the vicinity of water, which provide a major foraging habitat, are consistent with data published elsewhere (Glutz et al. 1971; Mebs 1989; Hagemeier and Blair 1997; Sergio et al. 2003a, b). As in our study area, the other European populations of Black Kite require the presence of water bodies within their territories. Such a tendency was also observed in southern Poland (Adamski 1992), where most breeding pairs occur along large rivers.

There are records in the literature of unfavourable population trends for both raptor species (BirdLife International 2019a, b), although in some countries like the UK, Sweden, Switzerland, Serbia, Denmark and the Czech Republic, populations of Red Kite have increased (Knott et al. 2009). However, we did not record any perceptible changes in numbers in our study plots, neither were there any significant changes of habitat structure at the breeding and foraging sites. Concern has been expressed regarding the dramatic expansion of large-area fields of tall crops (mostly maize) in western Poland (a similar situation exists, for example, in Sachsen-Anhalt-Eastern Germany Mammen et al. 2014), which could deplete food resources for kites. The Red Kite population in Wielkopolska will probably compensate for such habitat loss by seeking alternative food resources derived from human activities (mostly carrion), a fact that has already been corroborated by numerous field observations as well as regular studies of this species in Germany (Orros and Fellowes 2015; Nicolai et al. 2017; Cereghetti et al. 2019). On the other hand, the strategy adopted by Black Kite is presumably to focus on regions abundant in water bodies with a minimal proportion of maize fields. The fact that this species seems to thrive in such areas is endorsed by its stable population numbers and high level of breeding success. A potentially disturbing factor, however, is the high mortality of immature, first-year Red Kites, as revealed by telemetric studies on birds hatched in Poland (Maciorowski et al. 2019b). This appears to be a significant danger, potentially reducing the chances of recruitment of young birds into the future breeding population. Because of these threats, this population may become one of those whose numbers are declining (Mammen 2009; Nicolai et al. 2017; Katzenberger et al. 2019). To preserve both species of kites, the implementation of comprehensive conservation 
measures that focus on minimizing bird mortality on migration and in winter, as well as on the breeding and foraging sites of these raptors, would appear to be crucial.

Acknowledgements This project was a part of a study which examined the relationships between the Red Kite population's viability and environmental conditions in western Poland. The project was funded by the National Science Centre in Poland $(\mathrm{NCN})$ on the basis of decision No. DEC-2012/05/B/NZ9/03438. We would like to thank our colleagues Monika Broniszewska, Wojciech Czarnowski, Henryk Gierszal, Jarosław Gutowicz, Marek Ilków, Antoni Kasprzak, Marek Loritz, Paweł Mizera, Tadeusz Mizera, Fabrizio Sergio, Tomasz Statuch, Rafał Śniegocki and Piotr Tryjanowski for their cooperation and support in conducting this study. We also thank the anonymous reviewers for improving the manuscript and Peter Senn (native speaker) and Krzysztof Stępniewski for the language corrections.

Open Access This article is licensed under a Creative Commons Attribution 4.0 International License, which permits use, sharing, adaptation, distribution and reproduction in any medium or format, as long as you give appropriate credit to the original author(s) and the source, provide a link to the Creative Commons licence, and indicate if changes were made. The images or other third party material in this article are included in the article's Creative Commons licence, unless indicated otherwise in a credit line to the material. If material is not included in the article's Creative Commons licence and your intended use is not permitted by statutory regulation or exceeds the permitted use, you will need to obtain permission directly from the copyright holder. To view a copy of this licence, visit http://creativecommons.org/licenses/by/4.0/.

\section{References}

Adamski A (1992) Selected aspects of breeding ecology of the Black kite Milvus migrans Bodd 1783 in the Odra valley in Silesia. Univ Wroc Fac Nat Sci 112(3):351-362 (in Polish)

Adamski A (1994) Breeding ecology of the Red kite Milvus milvus in the middle Odra valley. Ptaki Śląska 10:19-36 (in Polish)

Aronson MFJ, La Sorte FA, Nilon CH, Katti M, Goddard MA, Lepczyk CA, Warren PS, Williams NSG, Cilliers S, Clarkson B, Dobbs C, Dolan R, Hedblom M, Kooijmans KS, Kühn I, MacGregor-Fors I, McDonnell M, Mörtberg U, Pyšek P, Siebert S, Sushinsky J, Werner P, Winter M (2014) A global analysis of the impacts of urbanization on bird and plant diversity reveals key anthropogenic drivers. Proc R Soc B 281:20133330

Berthold P (2001) Bird migration: a general survey. Oxford University Press on Demand, Oxford

BirdLife International (2019a) Species factsheet: Milvus migrans. https://www.birdlife.org. Accessed 6 Aug 2019

BirdLife International (2019b) Species factsheet: Milvus milvus. https://www.birdlife.org. Accessed 6 Aug 2019

Blanco G (2014) Can livestock carrion availability influence diet of wintering red kites? Implications of sanitary policies in ecosystem services and conservation. Popul Ecol 56:593-604

Camina A, Yosef R (2012) Effect of European Union BSE- related enactments on fledgling Eurasian Griffon (Gyps fulvus). Acta Ornithol 47:101-109

Carter I (2001) The Red Kite. Arlequin Press, Chelmsford, UK

Cereghetti E, Scherler P, Fattebert J, Grüebler MU (2019) Quantification of anthropogenic food subsidies to an avian facultative scavenger in urban and rural habitats. Landsc Urban Plan 190:103606
Cramp S, Simmons KEL (1980) The Birds of the Western Palearctic. Oxford University Press, Oxford

Davies PW, Davis PE (1973) The ecology and conservation of the Red Kite in Wales. Brit Birds 66:183-224

Devictor V, Julliard R, Couvet D, Lee A, Jiguet F (2007) Functional homogenization effect of urbanization on bird communities. Conserv Biol 21:741-751

Donald PF, Arendarczyk B, Spooner F, Buchanan GM (2018) Loss of forest intactness elevates global extinction risk in birds. Anim Conserv 22:341-347

(C) European Union, Copernicus Land Monitoring Service (2017) European Environment Agency (EEA)

Evans IM, Pienkowski MW (1991) World status of the Red Kite. Brit Birds 84:171-187

Fusch E (1980) Greifvogel bestandesaufriahmen im aarguischen Reßtal. Ornitol Beob 77:73-78

Gedeon K, Stubbe M (1991) Jahresbericht 1990 zum Monitoring Greifvögel und Eulen Europas - Jahresber. Monitoring Greifvögel Eulen Europas 3:7-55

Gedeon K, Stubbe M (1992) Jahresbericht 1991 zum Monitoring Greifvögel und Eulen Europas. - Jahresber. Monitoring Greifvögel Eulen Europas 4:1-53

Gedeon K, Stubbe M (1993) Jahresbericht 1992 zum Monitoring Greifvögel und Eulen Europas. - Jahresber. Monitoring Greifvögel Eulen Europas 5:1-68

Glutz von Blotzheim UN, Bauer KM, Bezzel E (1971) Handbuch der Vögel Mitteleuropas. Frankfurt, Frankfurt am Main

Grant SM (2007) The importance of Biodiversity in crop sustainability: a look at monoculture. J Hunger Environ Nutr 1:101-109

Guil F, Colomer MA, Moreno-Opoc R, Margalida A (2015) Spacetime trends in Spanish bird electrocution rates from alternative information sources. Glob Ecol Conserv 3:379-388

Hagemeier WJM, Blair MJ (eds) (1997) The EBCC atlas of European Breeding Birds: Their Distribution and Abudance. TAD Poyser, London

https://www.iucnredlist.org. Accessed 23 Aug 2019

Katzenberger J, Gottschalk E, Balkenhol N, Waltert M (2019) Longterm decline of juvenile survival in German Red Kites. J Ornithol 160:337-349

Knott J, Newbery P, Barov B (2009) Action plan for the red kite Milvus milvus in the European Union, pp 55. https://ec.europa.eu/envir onment/nature/conservation/wildbirds/action_plans/docs/milvu s_milvus.pdf. Accessed 6 Aug 2019

Król W (1985) Breeding density of diurnal raptors in the neighbourhood of Susz (Iława Lakeland, Poland) in the years 1977-79. Acta Ornithol 21:93-114

Maciorowski G (2017) The occurrence and conservation of the Black kite Milvus migrans in western Wielkopolska. Studia Mater CEPL Rogowie 19:92-99

Maciorowski G, Galanaki A, Kominos T, Dretakis M, Mirski P (2019) The importance of wetlands for the Greater Spotted Eagle Clanga clanga wintering in the Mediterranean Basin. Bird Conserv Int 29:115-123

Maciorowski G, Kosicki JZ, Polakowski M, Urbańska M, Zduniak P, Tryjanowski P (2019) Autumn migration of immature Red Kites Milvus milvus from a central European population. Acta Ornithol $54: 45-50$

Maciorowski G, Mirski P (2014) Habitat alteration enables hybridization between lesser spotted and greater spotted eagles in north-east Poland. Bird Conserv Int 24:152-161

Magurran A (2004) Measuring biological diversity. Blackwell, Oxford

Mammen U (2009) Situation and population development of Red Kites in Germany. In: Proceedings of the Red Kite international symposium, Oct 2009, Monttbeliard, France, pp 15-16

Mammen U, Nicolai B, Böhner J, Mammen K, Wehrmann J, Fischer S, Dornbusch G (2014) Artenhilfsprogramm Rotmilan des Landes 
Sachsen-Anhalt Berichte des Landesamtes für Umweltschutz Sachsen-Anhalt Halle. Heft 5:9

Mammen U, Stark I, Stubbe M (2017) Reproduction parameters of birds of prey and owls in Germany from 1988 to 2012. Populationsökol Greifvögel Eulenarten 7:9-28

Mebs T (1989) Greifvögel Europas. Biologie - Bestandsverhältnisse Bestandsgefährdung, Kosmos Naturführer, Stuttgart

Meyer CB, Meyer JS, Francisco AB, Holder J, Verdonck F (2016) Can ingestion of lead shot and poisons change population trend of three European birds: Grey Patridge, Common Buzzard, and Red Kite? PLoS ONE 11:e0147189

Molenaar FM, Jaffe JE, Carter I, Barnett EA, Shore RF, Rowcliffe JM, Sainsbury AW (2017) Poisoning of reintroduced red kites (Milvus milvus) in England. Eur J Wildl Res 63:94

Moreau RE (2009) Changes in Africa as a Wintering area for Palaearctic Birds. Bird Study 17:95-103

Morelli F, Benedetti Y, Ibáñez-Álamo JD, Jokimaki J, Mänd R, Tryjanowski P, Møller AP (2016) Evidence of evolutionary homogenization of bird communities in urban environments across Europe. Glob Ecol Biogeogr 25:1284-1293

Mougeot F, Bretagnolle V (2006) Breeding biology of the Red Kite Milvus milvus in Corsica. Ibis 148:436-448

Newton I (2010) The migration ecology of birds. Elsevier, London

Newton I (2010) Population ecology of raptors. A\&C Black, London

Newton I, Davis PE, Moss D (1996) Distribution and breeding of red kites Milvus milvus in relation to afforestation and other land-use in Wales. J Appl Ecol 33:210-224

Nicolai B (1995) Bestand und Bestandsentwicklung des Rotmilans (Milvus milvus) in Ostdeutschland Zeitschrift f. Vogelk. U. Natursch. in Hessen. Vogel Umv Sonderh 8:11-19

Nicolai B, Mammen U, Kolbe M (2017) Long-term changes in population and habitat selection of Red Kite Milvus milvus in the region with the highest population density. Vogelwelt 137:194-197

Orros ME, Fellowes MDE (2015) Widespread supplementary feeding in domestic gardens explains the return of reintroduced Red Kites Milvus milvus to an urban area. Ibis 157:230-238

Pfeiffer T, Meyburg BU (2015) GPS tracking of Red Kites (Milvus milvus) reveals fledgling number is negatively correlated with home range size. J Ornithol 156:963-975

Postupalsky S (1974) Raptor reproductive success: Some problems with methods, criteria and terminology. Raptor Res Rep 2:21-31

QGIS Development Team (2017) QGIS Geographic Information System. Open Source Geospatial Found Project. https://qgis.osgeo .org
Rutschke E (1983) Die Vogelwelt Brandenburgs. VEB Gustav Fisher Verlag, Jena

Schaub M (2012) Spatial distribution of wind turbines is crucial for the survival of red kite populations. Biol Conserv 155:111-118

Seaone J, Viñuela J, Diaz-Delgado R, Bustamante J (2003) The effects of land use and climate on Red Kite distribution in the Iberian peninsula. Biol Conserv 111:401-414

Seress G, Liker A (2015) Habitat urbanization and its effects on birds. Acta Zool Acad Sci Hung 61:373-408

Sergio F, Blas J, Forero M, Fernández N, Donázar JA, Hiraldo F (2005) Preservation of wide-ranging top predators by site-protection: Black and Red Kites in Doñana National Park. Biol Conserv 125:11-21

Sergio F, Pedrini P, Marchesi L (2003a) Adaptive selection of foraging and nesting habitat by black kites (Milvus migrans) and its implications for conservation: a multi-scale approach. Biol Conserv 112:351-362

Sergio F, Pedrini P, Marchesi L (2003) Reconciling the dichotomy between single species and ecosystem conservation: black kites and eutrophication in pre-Alpine lakes. Biol Conserv 110:101-111

Tavecchia G, Adrover J, Navarro AM, Pradel R (2012) Modelling mortality causes in longitudinal data in the presence of tag loss: application to raptor poisoning and electrocution. J Appl Ecol 49:297-305

Tenan S, Adrover J, Muñoz Navarro A, Sergio F, Tavecchia G (2012) Demographic consequences of poison-related mortality in a threatened bird of prey. PLoS ONE 7(11):e49187

Ter Braak CJF, Šmilauer P (2002) CANOCO Reference Manual and Cano Draw for Windows User's Guide: Software for Canonical Community Ordination (version 4.5). Biometris, Wageningen Ceské Budejovice

Traba J, Morales MB (2019) The decline of farmland birds in Spain is strongly associated to the loss of fallowland. Sci Rep 9:9473

Xu X, Xie Y, Qi K, Luo Z, Wang X (2018) Detecting the response of bird communities and biodiversity to habitat loss and fragmentation due to urbanization. Sci Total Environ 624:1561-1576

Publisher's Note Springer Nature remains neutral with regard to jurisdictional claims in published maps and institutional affiliations. 